\title{
Atlas of gene expression in the mouse kidney: new features of glomerular
}

\section{parietal cells}

\author{
Lydie Cheval, ${ }^{1,2}$ Fabien Pierrat, ${ }^{3}$ Carole Dossat, ${ }^{4}$ Mathieu Genete, ${ }^{1,2}$ Martine Imbert-Teboul,,${ }^{1,2}$ \\ Jean-Paul Duong Van Huyen, ${ }^{5}$ Julie Poulain, ${ }^{4}$ Patrick Wincker, ${ }^{4}$ Jean Weissenbach, ${ }^{4}$ David Piquemal, ${ }^{3}$ \\ and Alain Doucet ${ }^{1,2}$ \\ ${ }^{1}$ UPMC Univ Paris 06, Univ Paris Descartes and INSERM, UMRS 872, Centre de recherche des Cordeliers; ${ }^{2}$ CNRS, ERL \\ 7226, Laboratoire de génomique, physiologie et physiopathologie rénales, Paris; ${ }^{3}$ Skuld-Tech, Montpellier; ${ }^{4} \mathrm{CEA}, \mathrm{DSV}, \mathrm{IG}$, \\ Genoscope, Evry; and ${ }^{5}$ Hôpital européen Georges Pompidou, Paris, France
}

Submitted 11 May 2010; accepted in final form 8 November 2010

Cheval L, Pierrat F, Dossat C, Genete M, Imbert-Teboul M, Duong Van Huyen JP, Poulain J, Wincker P, Weissenbach J, Piquemal D, Doucet A. Atlas of gene expression in the mouse kidney: new features of glomerular parietal cells. Physiol Genomics 43: 161-173, 2011. First published November 23, 2010; doi:10.1152/physiolgenomics.00093.2010.-To gain molecular insight into kidney function, we performed a high-resolution quantitative analysis of gene expression in glomeruli and nine different nephron segments dissected from mouse kidney using Serial Analysis of Gene Expression (SAGE). We also developed dedicated bioinformatics tools and databases to annotate mRNA tags as transcripts. Over 800,000 mRNA SAGE tags were sequenced corresponding to $>20,000$ different mRNA tags present at least twice in at least one library. Hierarchical clustering analysis of tags demonstrated similarities between the three anatomical subsegments of the proximal tubule, between the cortical and medullary segments of the thick ascending limb of Henle's loop, and between the three segments constituting the aldosterone-sensitive distal nephron segments, whereas the glomerulus and distal convoluted tubule clusterized independently. We also identified highly specific mRNA markers of each subgroup of nephron segments and of most nephron segments. Tag annotation also identified numbers of putative antisense mRNAs. This database constitutes a reference resource in which the quantitative expression of a given gene can be compared with that of other genes in the same nephron segment, or between different segments of the nephron. To illustrate possible applications of this database, we performed a deeper analysis of the glomerulus transcriptome that unexpectedly revealed expression of several ion and water carriers; within the glomerulus, they were found to be preferentially expressed in the parietal sheet. It also revealed the major role of the zinc finger transcription factor $\mathrm{Wt1}$ in the specificity of gene expression in the glomerulus. Finally, functional annotation of glomerulus-specific transcripts suggested a high proliferation activity of glomerular cells. Immunolabeling for PCNA confirmed a high percentage of proliferating cells in the glomerulus parietal sheet.

nephron segment; glomerulus; Wt1; molecular markers; cell proliferation

UNTIL THE TURN OF THIS CENTURY, research in physiology mainly proceeded by reductionist strategies that focused on the function of a restricted number of proteins/genes selected either through a deductive approach (from function to cloning) or through reverse biology (from cloning to function). The function of these target genes was characterized in heterologous expression systems or in vivo since the invention

Address for reprint requests and other correspondence: A. Doucet, ERL7226, Centre de Recherche des Cordeliers, 15 rue de l'Ecole de Médecine, 75270 Paris cedex 6, France (e-mail: alain.doucet@crc.jussieu.fr). of sophisticated transgenesis methods (5). This approach proved highly productive as it led to the emergence of new concepts (e.g., moving from membrane permeability to channels) and of important outcomes (e.g., deciphering the molecular basis of genetic diseases). However, it also revealed its limitations, mainly because 1) properties of specific proteins vary with their cellular environment and 2) the overall properties of complex systems exceed the sum of the individual properties of their components.

The sequencing of entire mammalian genomes (14, 20, 36, 38 ), which theoretically gives access to the whole catalogue of genes potentially expressed in an organism, has opened the way to global analysis of systems. A first step in functional genomics is to identify the catalogue of genes that are actually expressed in a given tissue at a given time. Several reliable methods make possible exhaustive and reproducible analysis of the transcriptome, i.e., the catalogue of all the mRNAs expressed in biological samples $(2,23)$. Despite the limitation inherent to the characterization of transcripts rather than proteins for physiological purpose, the power of available methods for gene expression profiling combined with the current limitations of proteomic methods has boosted application of transcriptome analysis in many fields of physiology and pathophysiology: for example, searching PubMed for the "renal transcriptome" keywords retrieves over 800 references.

However, the output of transcriptome analysis in renal physiology and pathophysiology has remained limited mainly because kidneys are highly heterogeneous organs. As a matter of fact, we recently reported that differences in gene expression profiles observed between human kidney biopsies are accounted for by sample heterogeneity as much as by actual differences in gene expression levels (11). This study also showed that the structural heterogeneity can be circumvented by compartment analysis, inasmuch as a database for quantitative gene expression in the different compartments is available. Such pieces of information are available for the human nephron. Indeed, using microadaptation of Serial Analysis of Gene Expression (SAGE), it has been possible to establish the cartography of gene expression in the glomerulus and the main segments constituting the human nephron (7).

Since the development of methods for homologous recombination (5), the mouse has become the reference laboratory animal species almost universally used in kidney physiology and pathophysiology. Unfortunately, we only have limited data concerning the profile of gene expression in the mouse kidney: analysis of gene expression in mouse kidney concerns a restricted number of segments of the distal nephron $(8,37,40)$, 
and the limited depth of analysis in most studies restricts information to the most abundant transcripts. The main aim of this study was therefore to constitute a freely available database for quantitative gene expression profiles along the mouse nephron. This was achieved by combining microadaptation of SAGE with microdissection of mouse glomeruli and nephron segments. This database constitutes a reference resource in which the expression of a given gene can be compared with that of other genes in the same nephron segment or between different segments of the nephron. To illustrate the interest of this database, we have further investigated some unexpected findings concerning gene expression in the glomerulus.

\section{METHODS}

Animals. Animal experimentation was performed in accordance with the French legislation and under the responsibility of authorized experimenters (L.C., license \#75-1551; A.D., license \#75-699 renewal). Experiments were carried out on male 8-10 wk old CD1 mice (Charles River Breeding Laboratories) fed ad libitum a standard diet (A04, SAFE, Epinay, France).

Microdissection. Glomeruli and nephron segments were microdissected from liberase-treated kidneys, as previously reported (22). Briefly, the left kidney was perfused in situ with $6 \mathrm{ml}$ of Hanks' solution supplemented with $1 \mathrm{mM}$ glutamine, $1 \mathrm{mM}$ pyruvate, $0.5 \mathrm{mM}$ $\mathrm{MgCl}_{2}, 0.1 \%$ bovine serum albumin, $20 \mathrm{mM}$ HEPES, and $0.015 \%$ liberase (Blendzyme 2; Roche Diagnostics, Meylan, France), pH 7.4. Thin pyramids were cut from the kidney, incubated in $0.006 \%$ liberase solution for $20-25 \mathrm{~min}$ at $30^{\circ} \mathrm{C}$, and thoroughly rinsed in microdissection solution. All media were prepared and used in an RNase-free environment. In preliminary experiments, we verified that liberase treatment of kidneys did not alter the gene expression level (Supplemental Fig. S1). ${ }^{1}$

During microdissection, the different kidney structures were characterized on the basis of their appearance and location within the cortex and outer medulla (Supplemental Fig. S2). Glomeruli were isolated free from attached proximal tubules indifferently in superficial and deep cortex. The S1 and S2 portions of the proximal tubule (PT) were dissected in the cortex: the convoluted S1 segments corresponded to the first 1-1.5 $\mathrm{mm}$ attached to the glomeruli, whereas the straight S2 segments were dissected within the medullary rays. The S3 portions of PT, dissected in the outer medulla, corresponded to the $\sim 1 \mathrm{~mm}$ upstream from their connection with the thin segments of the Henle's loop. The medullary and cortical portions of the thick ascending limbs of Henle's loops (MTAL and CTAL) were dissected from the outer medulla (inner and outer stripe) and the cortex, respectively. They were easily distinguished from the adjacent tubules

${ }^{1}$ The online version of this article contains supplemental material. by their bright appearance. The distal convoluted tubules (DCT) were dissected just downstream the macula densa, and were restricted to their first V-shaped loop. Connecting tubules (CNT) were isolated within the cortex and were limited to portions located between successive branchings. The cortical and medullary collecting ducts (CCD and OMCD) were dissected within medullary rays, downstream their branching with other nephrons, and within the outer medulla (outer and inner stripe), respectively. They were easily distinguished from adjacent structures by their thickness and weak light reflex. After dissection, pools of identical structures from a single mouse were thoroughly rinsed and stored at $-80^{\circ} \mathrm{C}$ in lysis buffer until use.

Construction of SAGE libraries. Approximately 1,000 glomeruli or nephron segments microdissected from eight mice were used to generate each library. SAGE libraries were constructed according to the modified protocol adapted to small samples previously described (37). Sau3AI and MmeI were used as anchoring and tagging enzymes respectively. MmeI generates 15-bp-long tags (Long-SAGE). Automated DNA sequencing was carried out at the Genoscope (Evry, France). Sequence files analysis and tag extraction were performed using SAGE2000 software (7). Tags for linker-derived sequences were discarded, and those originating from duplicate ditags were retained (13).

Tag annotation and library curation. We generated a local database (Biotag, Skuld-Tech's platform) compiling Mus musculus sequences and related information from well-annotated sequences (Ensembl, E.B.I.), reference sequences of UniGene clusters (NCBI) and GenBank SINE (Short INterspersed Elements) mouse sequences. For each sequence of this database, the expected SAGE tag (canonical tag) located downstream the $3^{\prime}$-most Sau3AI restriction site (GATC) of the sequence (R1) as well as putative tags located in inner positions (labeled as R2, R3, and R4 starting from the 3' end of the transcript) were extracted (Fig. 1). From each anchoring site, virtual SAGE tags from the complementary strand, hereafter called "antisense tags" (AS1-AS4), were extracted also (Fig. 1). Experimental tags obtained from SAGE libraries were matched and annotated (exact matches for the $15 \mathrm{bp}$ ) using this collection of virtual tags $(29,30)$. Experimental tags matching several virtual tags were annotated either as multiple matches if the different annotations corresponded to unrelated transcripts or as a single transcript when the different annotations corresponded to variants of that transcript.

With single-pass sequencing, a $1 \%$ error rate is routinely obtained, which translates to a SAGE tag error rate of $14 \%\left(1-0.99^{15}\right)$. Because sequencing errors are essentially random, they likely generate tags without match and inflate the number of different tags. Thus, we evaluated whether tags without match could be accounted for by mutation of well-annotated tags. For this purpose we developed a macro (available upon request) to identify whether the sequence of no-match tags differed from that of any annotated tag in the library by either a single nucleotide mutation or a single nucleotide frame shift in either direction. When the occurrence of such potentially mutated
Fig. 1. Principle of tag annotation. Each tag was annotated after matching against a collection of virtual tags derived from a database of mouse transcripts sequences. For each sequence, we defined a canonical tag (R1) located downstream the $3^{\prime}$-most Sau3AI restriction site (GATC) of the sequence (R1) as well as 3 upper tags (R2-R4) located downstream upper GATC motifs. Four antisense tags (AS1-AS4) were derived from the corresponding GATC motifs on the virtual complementary DNA strand. The table at bottom displays the normalized abundance of the different Kap tags in the 3 subsegments of the proximal tubule (PT).

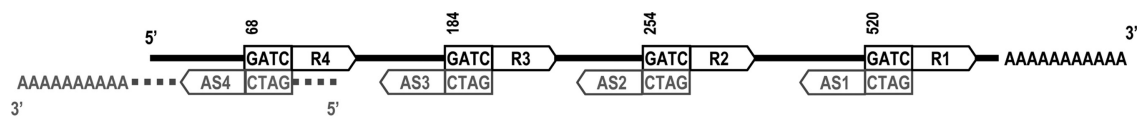

\begin{tabular}{|l|c|c|c|c|}
\hline Tag sequence & Rank & S1 & S2 & S3 \\
\hline CTGGATGAGAAATGC & R1 & 4459.3 & 7459.2 & 7676.3 \\
\hline ATGGACTTCACGCCA & R2 & 295.9 & 1908 & 408.3 \\
\hline ATACAGAGGGACAAA & R3 & 22.1 & 57.3 & 31.9 \\
\hline ACTGTCTTCTGTGGT & R4 & 1.8 & 10.3 & 10.6 \\
\hline ACTTCCTCGTTCTTT & AS1 & 443.2 & 398.7 & 422.2 \\
\hline TGCTCAGAGTCAGTG & AS2 & 28.7 & 57.7 & 51.1 \\
\hline CCAGTTGGTCAAAGA & AS3 & 22.7 & 38.2 & 31.9 \\
\hline ACCAGGACCTTGAAA & AS4 & 684.2 & 2032.5 & 1850.9 \\
\hline
\end{tabular}


tags was $>1$ and $\leq 14 \%$ of the occurrence of the cognate wellannotated tags, the tag was dismissed after its occurrence was added to that of the well-annotated tag. All potentially mutated tags with occurrence of 1 were dismissed.

Hierarchical clustering. Differential expression profiles were analyzed using Cluster software (12), a hierarchical average linkage clustering algorithm freely available on the web (http://rana.lbl.gov/ EisenSoftware.htm). This algorithm used an iterated, agglomerative process of similarity measurements based on the Pearson correlation. In each iterative step of the algorithm, the two most similar data elements (i.e., expression profiles) were joined by a node of a dendrogram, after which the joined elements were averaged and replaced by a pseudo-element that was used in all subsequent iterations. Before clustering, data were submitted to gene normalization (fivefold), which sets the magnitude (the sum of the squares of the values of tag occurrences in the 10 libraries) of each transcript vector to 1 . This gives a same weight to high-abundance and low-abundance transcripts in the analysis. Results from Cluster data treatment were graphically visualized using TreeView software also freely available at the same web address.

Functional annotation. Functional annotation of tags was limited to unambiguous tag-derived transcripts, i.e., tags with single R1 annotation. Ontologic classification according to processes or functions was performed using GO_Slim Chart Tool available as a Mouse Genome Informatics resource (http://www.informatics.jax.org/).

$m R N A$ extraction and RT-real time PCR analysis. RNAs were extracted, according to the technique previously described (8), from pools of 20-50 glomeruli or nephron segments. RNAs were reverse transcribed using the first-strand cDNA synthesis kit for RT-PCR (Roche Diagnostics, Meylan, France), according to the manufacturer's protocol. Real-time PCR was performed on a LightCycler (Roche Diagnostics) with the LightCycler FastStart DNA Master SYBR Green 1 kit (Roche Diagnostics) according to the manufacturers' protocols, except that the reaction volume was reduced 2.5 -fold. PCR was performed with cDNA quantity corresponding to $1 / 5$ th of a glomerulus or $0.1 \mathrm{~mm}$ of the different segments of nephron. No DNA was detectable in samples that did not undergo reverse transcription, and in blanks run without cDNA. In each experiment, a standardization curve was made using serial dilutions of a standard cDNA stock solution made from either whole kidney or specific nephron segment RNA. Unless otherwise indicated, the amount of PCR product was calculated as percent of the standard DNA and results (arbitrary unit per glomerulus or mm tubule length) were calculated as means $\pm \mathrm{SE}$ from several animals. Specific primers (Supplementary Table S1) were designed using LightCycler ProbeDesign 2 (Roche Diagnostics).

Immunohistochemistry. Immunohistochemistry was performed either on kidney sections or on isolated glomeruli when low expression levels, compared with other kidney structures, were searched for. Microdissected glomeruli were transferred to Superfrost Gold + glass slides, rinsed twice with calcium- and magnesium-containing PBS, and fixed for 20 min with paraformaldehyde (4\% in Ca-Mg-PBS). Afterwards, they were incubated $20 \mathrm{~min}$ at room temperature in 100 $\mathrm{mM}$ glycine in PBS, rinsed thrice in PBS, permeabilized for $30 \mathrm{~s}$ with $0.1 \%$ triton in PBS, and rinsed with PBS. After being blocked in PBS containing $0.5 \%$ BSA and $5 \%$ goat serum for $30 \mathrm{~min}$ at room temperature, slides were incubated with primary antibodies: anti$\mathrm{Na}, \mathrm{K}$-ATPase $\alpha$-subunit $(1 / 500,1 \mathrm{~h}$ at room temperature; gift of $\mathrm{G}$. Crambert), anti-AQP2 (1/400, $1 \mathrm{~h}$ at room temperature; Sigma). After being rinsed with PBS-Tween $0.05 \%$ (once) and PBS (twice), slides were incubated with the secondary antibody $(1 / 500,1 \mathrm{~h}$ at room temperature): TRITC-coupled anti rabbit IgG (for Na,K-ATPase) or FITC-coupled anti rabbit IgG (for AQP2). After being rinsed once with PBS-Tween and twice with PBS, slides were mounted with DakoGel and observed on a confocal microscope $(\times 40$, Zeiss observer.Z1, LSM710).

Kidneys were fixed by in situ perfusion, removed, sliced in four sections, and fixed in formalin for additional $18 \mathrm{~h}$ before paraffin embedding. Immunohistochemistry was performed on $5 \mu \mathrm{m}$ thick kidney sections with a monoclonal anti-PCNA antibody (PC10 clone, 1/200, DAKO) with prior antigen unmasking procedure. Secondary anti-mouse biotinylated antibody (1/200) and streptavidin-peroxidase amplification ELITE kit were from Vector laboratories (Burlingame, CA).

\section{RESULTS}

Generation of gene expression database from mouse glomeruli and nephron segments. SAGE libraries were generated from glomeruli and nine segments of nephron from adult mice: the S1, S2, and S3 subsegments of the proximal tubule (PT), the MTAL and CTAL, the DCT, the CNT, and the CCD and OMCD. The number of sequenced tags was adjusted to provide at least 50,000 tags per library after curation, yielding a total of 804,225 tags corresponding to 74,394 different tags in the whole project (Supplemental Table S2). Assuming a total number of 300,000 mRNAs per cell, it can be calculated from Clarke and Carbon (9) that analysis of 50,000; 70,000; and 100,000 tags provides a $95 \%$ confidence of detecting transcripts expressed at 18,13 , and 10 copies per cell, respectively. For further comparisons between libraries, all tag counts were normalized to 50,000 tags per library (Supplemental Table S3). Libraries were deposited on Gene Expression Omnibus (accession number GSE25223).

Only $30 \%$ of the 74,394 different tags were counted at least twice in a given library, but $>70 \%$ of them could be annotated in our database. In contrast, only $35 \%$ of tags counted only once in a library could be annotated (Supplemental Table S4), suggesting that most of them are artefacts due to sequencing errors. Over $40 \%$ of annotated tags corresponded to the expected $3^{\prime}$-most position of cDNA (R1), and $30 \%$ matched to the reverse cDNA sequence (AS), suggesting the existence of a large number of antisense RNAs (Supplemental Table S4).

Except in the PT, the most abundant tag in each structure (0.6-1.8\% of all transcripts) corresponded to a transcript encoded by the mitochondrial genome, as previously observed in the human nephron (7). By contrast, the most abundant tag in
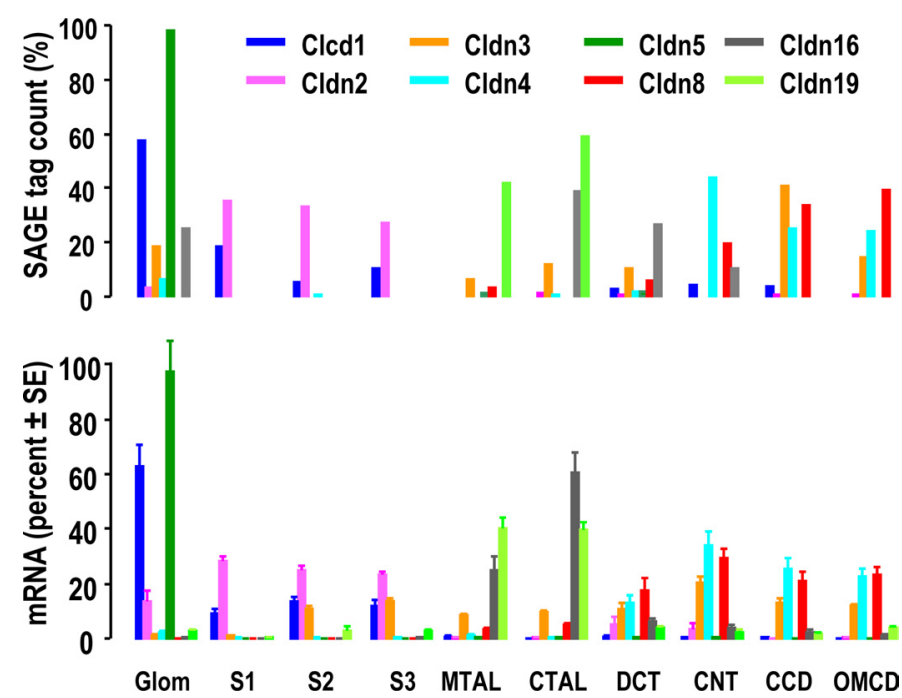

Fig. 2. Expression of claudins along the mouse nephron. Expression of claudin mRNAs as determined by SAGE (top) and RT-QPCR (bottom) in the different structures of the mouse kidney. PCR values are means \pm SE from 5 or 6 animals. In both cases, results were expressed as percent of the sum in the different structures. 
the three subsegments of the PT, which accounted for 8.9$15.3 \%$ of all transcripts, was that of the kidney androgenregulated protein (Kap). This tag was the most abundant in the whole project. As a matter of fact, the four sense tags (R1-R4) corresponding to Kap were present at various abundance in PT libraries. In all subsegments of PT, the abundance of Kap tags markedly decreased from S1 to S2, and so forth to S4 (Fig. 1), as expected if the inner tags were due to uncompleted cleavage

Table 1. Selection of kidney segment-specific and-enriched transcripts

\begin{tabular}{l} 
MGI Sequence Definition (Sy \\
\hline Plasminogen activator, tissue (Plat) \\
Myomesin 2 (Myom2) \\
Podocalyxin-like (Podxl) \\
Nephrosis 2 homolog, podocin (Nhsp2) \\
Placenta specific 9 (Plac9) \\
Claudin 5 (Cldn5) \\
Chloride intracellular channel 3 (Clic3) \\
\\
Transcribed locus (EST) \\
Expressed sequence AI481121 (AI481121) \\
Myo-inositol oxygenase (Miox) \\
NADPH oxidase 4 (Nox4) \\
Glucose-6-phosphatase, catalytic (G6pc) \\
Glycine decarboxylase (Gldc)
\end{tabular}

Hydroxysteroid 11-beta dehydrogenase 1 (Hsd11b1)

Solute carrier family 22, member 13 (Slc22a13)

Sushi domain containing 3 (Susd3)

Thyrotroph embryonic factor (Tef)

Transmembrane protein 86A (Tmem86a)

Transcribed locus (EST)

Src homology 2 domain-containing transforming protein D (Shd)

Death-associated protein kinase 1 (Dapk1)

Solute carrier family 12 , member 3 (Slc12a3)

Phosphoglycerate mutase 2 (Pgam2)

RELT-like 1 (Rell1)

WNK lysine-deficient protein kinase 1 (Wnk1)

parvalbumin (Pvalb)

RIKEN cDNA C030007I09 gene (C030007I09Rik)

Oxoglutarate (alpha-ketoglutarate) receptor 1 (Oxgr1)

Acyl-CoA syntHETASE long-chain family member 5 (Acs15)

Transcribed locus (EST)

Solute carrier family 37 , member 3 (Slc37a3)

Mucolipin 3 (Mcoln3)

Actinin alpha 3 (Actn3)

Rho, GDP dissociation inhibitor (GDI) beta (Arhgdib)

CD79B antigen (Cd79b)

Aquaporin 6 (Aqp6)

Elastin microfibril interfacer 2 (Emilin2)

Checkpoint with forkhead and ring finger domains (Chfr)

$\begin{array}{rrr}\mathbf{4 5 . 8} & & \\ \mathbf{2 5 . 3} & & \\ \mathbf{1 1 4 7 . 5} & 1.2 & 4 . \\ \mathbf{9 1 2 . 0} & & 1 . \\ \mathbf{6 2 . 6} & & 0.5 \\ \mathbf{5 9 . 8} & & \\ \mathbf{3 9 . 3} & & \end{array}$

1.5

39.3

4.7

4.6

$\begin{array}{lll}6.4 & 7.3 & 5.4\end{array}$

0.7

S1-enriched transcripts

$\begin{array}{rrrr}1.0 & \mathbf{2 2 . 1} & 1.5 & 0.7 \\ & \mathbf{1 6 . 1} & & 0.7 \\ 3.8 & \mathbf{2 8 6 . 9} & 40.6 & 41.2 \\ & \mathbf{1 4 . 3} & 1.5 & 1.4 \\ & \mathbf{1 2 . 6} & 2.0 & 1.4 \\ & \mathbf{9 . 0} & 1.0 & \end{array}$

0.5
1.0

0.6

2.3

0.8

$14.2 \quad 2.2$

0.7

1.0

0.7

1.4

S3-enriched transcripts

$\begin{array}{lllllll} & & 0.5 & \mathbf{7 . 3} & 0.6 & & \\ & & 0.5 & \mathbf{6 . 7} & & & 0.5 \\ 1.0 & 1.2 & 1.0 & \mathbf{8 . 0} & 0.6 & & 1.5 \\ 1.0 & & 0.5 & \mathbf{8 . 0} & 0.6 & 0.6 & 1.0\end{array}$

MTAL-enriched transcripts

$\begin{array}{lll}1.0 & 0.6 \quad 0.5\end{array}$

5.8

$\mathbf{8 . 7} \quad 1.7$

7.0 0.6

0.5

1.5

CTAL-enriched transcripts )

$\begin{array}{llllllll}1.0 & 0.6 & 0.7 & 0.6 & \mathbf{8 . 0} & & & \\ & & 0.6 & 0.5 & 0.8 & 0.7\end{array}$

DCT-enriched transcripts

$\begin{array}{ll}1.9 & \\ 1.9 & 0.5 \\ 1.9 & 0.5 \\ 1.0 & \end{array}$

$\begin{array}{rrrrr} & & \mathbf{2 3 . 0} & 0.8 & \\ 2.9 & 0.6 & \mathbf{1 0 4 . 8} & 5.9 & 12.8 \\ 0.6 & 3.4 & \mathbf{3 2 . 8} & & 2.0 \\ & 3.4 & \mathbf{3 2 . 8} & 1.5 & 3.4\end{array}$

CNT-enriched transcripts

$\begin{array}{rrrrrrrr}1.2 & & 1.4 & & 0.6 & & \mathbf{1 3 . 9} & 1.4 \\ & & & & & 0.5 & \mathbf{8 . 0} & 0.7 \\ & 2.0 & 1.4 & 4.7 & 4.0 & 3.5 & \mathbf{3 6 . 5} & 6.1 \\ & & & & 0.6 & 0.5 & \mathbf{6 . 6} & 0.7 \\ 0.6 & 1.0 & 0.7 & & & 0.5 & \mathbf{5 . 1} & 0.7\end{array}$

CCD-enriched transcripts

OMCD-enriched transcripts

\begin{tabular}{|c|c|c|c|c|c|}
\hline \multirow{3}{*}{0.6} & & & 1.5 & 9.4 & 1.4 \\
\hline & \multirow{2}{*}{0.6} & & 3.7 & 1.4 & $\begin{array}{r}5.0 \\
39.0\end{array}$ \\
\hline & & 0.5 & $\begin{array}{r}20.4 \\
0.8\end{array}$ & $\begin{array}{r}23.5 \\
0.7 \\
0.7\end{array}$ & $\begin{array}{r}124.8 \\
7.1 \\
5.0\end{array}$ \\
\hline
\end{tabular}

Values are normalized to 50,000 tags in each structure; empty boxes denote the absence of tag. All selected transcripts correspond to unambiguously annotated tags (R1 rank). Genes are identified according to the Mouse Genome Informatics (MGI) definition and symbol (in parenthesis). Glom, glomerulus; MTAL, medullary thick ascending limb of Henle's loop; CTAL, cortical thick ascending limb of Henle's loop; DCT, distal convoluted tubule; CNT, connecting tubule; $\mathrm{CCD}$, cortical collecting duct; OMCD, outer medullary collecting duct. Transcripts shown in boldface are those selected for verification of their distribution profile along the nephron by RT-PCR (see Fig. 3). 

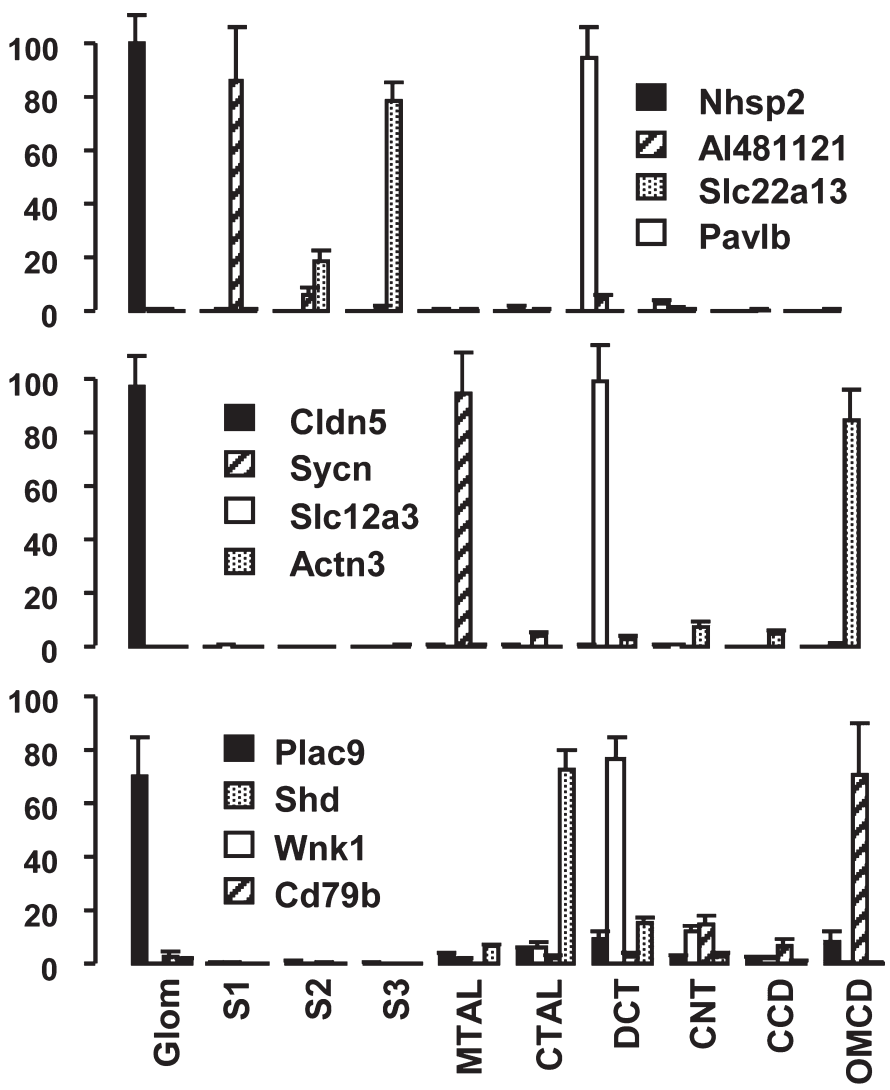

Fig. 3. Expression of glomerulus- and segment-specific markers along the mouse nephron. Expression of SAGE-derived structure markers was determined by RT-QPCR on microdissected glomeruli and nephron segments. For each transcript, results are expressed as percent $\pm \mathrm{SE}$ of the sum in the different structures. We verified the specificity of markers for the glomerulus (Glom) (Nhsp2, Cldn5, and Plac9), the S1 and S3 parts of the PT (AI481121 and Slc22a13, respectively), the medullary and cortical thick ascending limb of Henle's loop (MTAL, CTAL) (Sync and Shd, respectively), the distal convoluted tubule (DCT) (Pavlb, Slc12a3, and Wnk1), and the outer medullary collecting duct (OMCD) (Actn3 and Cd79b).

of cDNA by the tagging enzyme Sau3AI. Despite its very high abundance, the function of Kap, a protein expressed in rodents but not in humans, remains elusive.

We tried to evaluate the degree of cross contamination between libraries. Because it is not possible to determine whether the presence of a tag in a given library reflects true expression in the cognate tissue or contamination by another tissue, we could only estimate a maximal degree of possible cross contamination. The maximal contamination of a library A by a library B was calculated as the lowest value of the ratios of tag abundances in A over B library. Given the limits of the method to detect low abundance tags, a tag abundance of 1 was arbitrarily taken for calculating these ratios when the tag was not counted in library A, an approximation that over evaluates cross contamination level. Results (Supplemental Table S5) indicate very low cross contaminations (0.03-1.3\%) except between the sub segments of the PT (1.5-3.6\%), the MTAL and CTAL (4-5\%), and the terminal segments of the nephron $(1.5-5 \%)$. Because it is highly unlikely to contaminate cortical structures with medullary ones (S1 and S3; MTAL and CTAL; CNT and OMCD), and vice versa, these relatively higher levels of maximal contamination likely reflect the resemblance of these subgroups of structures (see below) rather than actual contamination.

This SAGE database is anticipated to serve for the comprehensive analysis of gene expression. As an illustration, we screened the mouse nephron database for the expression of 374 genes that confer tissue transport and permeability properties (Supplemental Table S6). As an example of validation of SAGE data, we confirmed by RT-PCR the expression profiles of several claudins in the glomerulus and along the nephron (Fig. 2).

Identification of segment-enriched transcripts. Tags enriched in a given kidney structure were selected according to stringent criteria: an occurrence $\geq 5 / 50,000$ and a fivefold enrichment in one structure compared with all others. We identified 446 tags meeting these criteria, most of which (350/446) were enriched in the glomerulus (Supplemental Table S7). A selection of kidney structure-enriched transcripts is shown in Table 1. Some among them were selected for RT-PCR confirmation of their specific distribution profile along the nephron (Fig. 3). Interestingly, we identified markers able to discriminate closely related structures such as the S1 and S3 subsegments of the PT, or the cortical and medullary portions of either the thick ascending limb of Henle's loop or the collecting duct.

Hierarchical clustering and functional specificities. Hierarchical clustering of the 8,861 different tags counted at least $2.5 / 50,000$ in one library disclosed similarities in expression profiles within subgroups of nephron segments: the three subsegments of the PT (S1, S2, and S3), the medullary and cortical portions of the thick ascending limb of Henle's loop (TAL: MTAL and CTAL), and three segments of the aldosteronesensitive distal nephron (ASDN: CNT, CCD and OMCD), respectively. The DCT was more closely related to the TAL than to the ASDN, and the glomerulus was rather distant from all other clusters of tubular structures (Fig. 4).

Based on these results, we searched for specific markers of these five kidney regions. Tags enriched in one of these regions were selected according to the following criteria: an occurrence $\geq 5 / 50,000$ and a 10-fold enrichment in one region compared

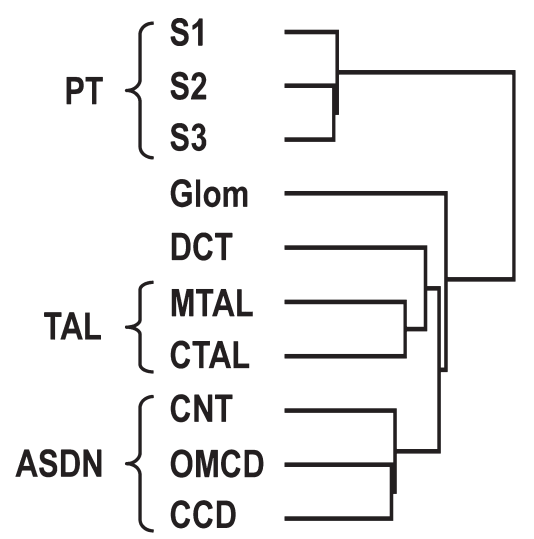

Fig. 4. Hierarchical clustering of gene expression in mouse kidney structures. Clustering according to tag abundance of the 8,861 tags counted at least $2.5 / 50.000$-fold in at least one library was performed using Cluster software. The dendogram showing relationships between libraries was graphically visualized using TreeView software. It discloses subgroups of structures with similar patterns of gene expression: the 3 subsegments of the PT and of the aldosterone-sensitive distal nephron (ASDN) as well as the 2 subsegments of the thick ascending limb of Henle's loop (TAL). 
with the four others. We identified 344 such tags in the glomerulus, 168 in PT, 19 in TAL, 20 in DCT, and 25 in late ASDN, including 287 region-specific tags present in a single region (Supplemental Table S8). A selection of region-enriched tags is shown in Table 2.

To address whether this structure specificity of gene expression reflects functional specificities, we performed functional classification according to Gene Ontology. This analysis was limited to unambiguous tag-derived transcripts, i.e., tags with single R1 annotation. It was also restricted to the comparison between glomeruli and proximal tubules, the two structures with a large and comparable number of specific transcripts (96 and 90 specific transcripts respectively). Results in Table 3 show expected func- tional differences, such as the overrepresentation of transcripts involved in transport and metabolism in the PT compared with the glomerulus and to the whole mouse transcriptome. They also reveal unexpected specificities of the glomerulus, including a higher representation of transcripts involved in regulation (signal transduction activity and kinase activity), in gene expression (transcription regulatory activity, nucleic acid binding activity, RNA metabolism), and in cell proliferation and differentiation (cell cycle and proliferation, cell organization and biogenesis, protein metabolism) than in PT and whole mouse transcriptome.

Expression of transport proteins in the glomerulus. Nonetheless, Supplemental Table S6 unexpectedly indicates that several transcripts encoding proteins involved in ion and water

Table 2. Examples of kidney region-specific and-enriched tags

\begin{tabular}{l}
\hline \hline \multicolumn{1}{c}{ MGI Sequence Definition } \\
\hline Podocalyxin-like \\
Nephrosis 2 homolog, podocin (human) \\
Placenta specific 9 \\
Claudin 5 \\
Plasminogen activator, tissue \\
Chloride intracellular channel 3 \\
Synaptopodin \\
Lectin, galactose binding, soluble 9 \\
Tudor domain containing 5 \\
Myomesin 2 \\
Dendrin \\
HtrA serine peptidase 1 \\
Kinase insert domain protein receptor
\end{tabular}

Kidney androgen regulated protein

Aspartoacylase (aminoacylase) 3

Kidney expressed gene 1

Acyl-CoA synthetase medium-chain family member 2

Solute carrier family 17 (sodium phosphate), member 1

UDP glycocyltransferase 3 family, polypeptide A2

Alanyl (membrane) aminopeptidase

Uromodulin

Solute carrier family 12 , member 1

Expressed sequence AI844685

RIKEN cDNA $1190020 J 12$ gene

Phospholipase A1 member A

Claudin 19, transcript variant 2

Protein phosphatase 1 , regulatory (inhibitor) subunit $1 \mathrm{~B}$

Phoshoglycerate mutase 2

RELT-like 1

WNK lysine deficient protein kinase 1

Solute carrier family 12 , member 3

Parvalbumin

Aquaporin 2

Solute carrier family 4 (anion exchanger), member 1

Aquaporin 6

Arginine vasopressin receptor 2

Sodium channel, nonvoltage-gated 1 gamma

Rho, GDP dissociation inhibitor (GDI) beta

Prostaglandin E receptor 1 (subtype EP1)

\begin{tabular}{lr}
\multicolumn{1}{c}{ MGI Symbol } & \multicolumn{2}{c}{ Glom } \\
\hline \multicolumn{2}{c}{ Glomerulus-enriched tags } \\
Podxl & 1147.5 \\
Nphs2 & 912.0 \\
Plac9 & 62.6 \\
Cldn5 & 59.8 \\
Plat & 45.8 \\
Clic3 & 39.2 \\
Synpo & 37.4 \\
Lgals9 & 37.4 \\
Tdrd5 & 25.2 \\
Myom2 & 25.2 \\
Ddn & 21.5 \\
Htra1 & 20.6 \\
Kdr & 15.9 \\
\multicolumn{1}{c}{ PT-enriched tags } & \\
&
\end{tabular}

Kap

Acy3

Keg1

Acsm2

Slc17a1

Ugt3a2

Ugt3a1

$\begin{array}{rr}287.8 & 6,531.6 \\ & 337.7 \\ 1.9 & 109.3 \\ & 109.0 \\ & 49.2 \\ & 37.3 \\ & 7.2\end{array}$

TAL-enriched tags

Umod
Slc12a1
AI844685
1190020J12Rik
Pla1a
Cldn19
Ppp1r1b

17.8

4.7

DCT-enriched tags

$\begin{array}{ll}\text { Pgam2 } & 1.9\end{array}$

Rell1 1.9

Wnk1 1.9

Slc12a3 23.0

Pvalb

330.4
58.6
24.5
24.3
8.1
7.8
7.5

14.7

1.4

1.6

0.5

ASDN-enriched tags

$\begin{array}{ll}\text { Aqp2 } & 45.8 \\ \text { Slc4a1 } & 13.1 \\ \text { Aqp6 } & \\ \text { Avpr2 } & \\ \text { Scnn1 g } & \\ \text { Arhgdib } & \\ \text { Ptger1 } & \end{array}$

Values are normalized to 50,000 tags in each region; empty boxes denote the absence of tag. Genes are identified according to the MGI nomenclature, including the symbol and the sequence definition. PT, proximal tubule; TAL, thick ascending limb of Henle's loop; DCT, distal convoluted tubule; ASDN, aldosterone-sensitive distal nephron. 
Table 3. Functional classification of glomerulus- and proximal tubule-enriched transcripts

\begin{tabular}{|c|c|c|c|c|c|c|}
\hline & \multicolumn{2}{|c|}{ Glomerulus } & \multicolumn{2}{|c|}{ PT } & \multicolumn{2}{|c|}{ All MGI } \\
\hline & Count & $\%$ & Count & $\%$ & Count & $\%$ \\
\hline \multicolumn{7}{|c|}{ Function } \\
\hline Signal transduction activity & 16 & 16.7 & 3 & 3.3 & 3,321 & 9.7 \\
\hline Transporter activity & 2 & 2.1 & 15 & 16.7 & 972 & 2.8 \\
\hline Enzyme regulator activity & 5 & 5.2 & 4 & 4.4 & 624 & 1.8 \\
\hline Extracellular structural activity & 0 & 0 & 0 & 0 & 24 & 0.1 \\
\hline Bone, tooth or skin structural activity & 0 & 0 & 0 & 0 & 4 & 0 \\
\hline Cytoskeletal activity & 2 & 2.1 & 0 & 0 & 480 & 1.4 \\
\hline Transcription regulatory activity & 11 & 11.5 & 0 & 0 & 1,064 & 3.1 \\
\hline Translation activity & 0 & 0 & 0 & 0 & 45 & 0.1 \\
\hline Chaperone-related activity & 0 & 0 & 0 & 0 & 0 & 0.0 \\
\hline Nucleic acid binding activity & 15 & 15.6 & 0 & 0 & 2,464 & 7.2 \\
\hline Kinase activity & 8 & 8.3 & 0 & 0 & 769 & 2.2 \\
\hline Unknown molecular function & 0 & 0 & 0 & 0 & 0 & 0 \\
\hline Other molecular function & 96 & 100 & 90 & 100 & 31,452 & 91.8 \\
\hline All molecular function & 96 & 100 & 90 & 100 & 34,256 & 100 \\
\hline \multicolumn{7}{|c|}{ Process } \\
\hline Cell adhesion & 5 & 5.2 & 5 & 5.6 & 593 & 1.7 \\
\hline Cell-cell signaling & 0 & 0 & 0 & 0 & 327 & 1.0 \\
\hline Cell cycle and proliferation & 16 & 16.7 & 0 & 0 & 1,227 & 3.6 \\
\hline Death & 4 & 4.2 & 4 & 4.4 & 811 & 2.4 \\
\hline Cell organization and biogenesis & 11 & 11.5 & 3 & 3.3 & 1,872 & 5.5 \\
\hline Protein metabolism & 16 & 16.7 & 6 & 6.7 & 2,559 & 7.5 \\
\hline DNA metabolism & 0 & 0 & 0 & 0 & 397 & 1.2 \\
\hline RNA metabolism & 15 & 15.6 & 0 & 0 & 2,567 & 7.5 \\
\hline Other metabolic processes & 12 & 12.5 & 48 & 53.3 & 2,738 & 8.1 \\
\hline Stress response & 5 & 5.2 & 3 & 3.3 & 1,149 & 3.4 \\
\hline Transport & 4 & 4.2 & 19 & 21.1 & 2,312 & 6.8 \\
\hline Developmental processes & 24 & 25.0 & 10 & 11.1 & 2,564 & 7.5 \\
\hline Signal transduction & 25 & 26.0 & 2 & 2.2 & 3,545 & 10.4 \\
\hline Unknown biological processes & 0 & 0 & 0 & 0 & 0 & 0 \\
\hline Other biological processes & 96 & 100 & 90 & 100 & 28,216 & 83.0 \\
\hline All biological processes & 96 & 100 & 90 & 100 & 34,006 & 100 \\
\hline
\end{tabular}

Unambiguously defined transcripts enriched in glomeruli or PT were classified according to Gene Ontology functions and processes. For comparison, classification of all transcripts deposited in MGI is shown. In boldface are shown the classes that are overrepresented compared with whole mouse transcriptome.

transport are expressed in the mouse glomerulus. These include proteins expressed along the whole nephron (Na,K-ATPase and H-ATPase subunits) or enriched in specific structures including the PT (e.g., the Na-glucose cotransporter Slc5a2, the amino-acid transporter Slc7a13, and the water channel Aqp1), the TAL (e.g., the chloride channel Clcknb and the $\mathrm{Na}-\mathrm{K}-2 \mathrm{Cl}$ cotransporter Slc12a1), and the ASDN (e.g., the $\mathrm{Cl}-\mathrm{HCO}_{3}$ exchanger Slc4a1, the $\alpha$ - and $\beta$-subunits of the epithelial $\mathrm{Na}$ channel Scnn1a and Scnn1b, and the aquaporins Aqp2 and Aqp3). Their presence in glomeruli cannot be accounted for by cross contamination between libraries because their relative level of expression in glomeruli versus their main tubular site of origin (6-100\%, see Supplemental Table S6) by far exceeds maximal cross contamination of glomeruli by these structures (0.2-1\%, see Supplemental Table S5).

The glomerulus consists of two distinct components: the glomerular tuft, containing the capillary bundle, the podocytes, and the mesangium, which is the filtration structure, and the parietal sheet of Bowman's capsule that protracts the PT and limits the urinary space. To determine the cellular origin of glomerular transporters, we compared by RT-PCR their expression in microdissected parietal epithelium and in glomerular tuft. Figure 5 shows that most of these transcripts preferentially originated from the parietal sheet, whereas, as expected, the podocyte markers podocalyxin (Podxl) and podocin (Nphs2) were exclusively expressed in the glomerular tuft.
In mouse, the parietal sheet of the glomerulus consists of two distinct cell types: the urinary pole appears as an extension of the PT and is made of well differentiated proximal tubulelike cells (PTLCs) displaying an apical brush border, whereas the vascular pole is made of flattened cells referred to as parietal epithelial cells (PECs) (Fig. 6, $A$ and $B$ ). Immunohistology on isolated glomeruli confirmed the expression of $\mathrm{Na}, \mathrm{K}$ ATPase $\alpha$-subunit and indicated its presence at the basolateral pole of PTLCs but neither in PECs nor in the glomerular tuft (Fig. 6, $D$ and $F$ ). It also showed that PTLCs express intracellular Aqp2 (Fig. 6, $H$ and $J$ ). Intensity of Na,K-ATPase labeling was similar in PT and parietal sheet (Fig. 6), whereas AQP2 labeling was much weaker in glomeruli than in collecting ducts (not shown).

Wt1 and specificity of gene expression in the glomerulus. Tissue specificity of gene expression results from tissue-specific expression of transcriptional regulators. Since the glomerulus specifically expresses several transcription factors, we tried to identify their targets among genes specifically expressed in the glomerulus. For this purpose, we searched for the DNA binding site of the transcription factors in the putative promoter regions of genes encoding glomerulus-enriched transcripts. This analysis was restricted to the zinc finger transcription factor Wt1 because it is the only structure-specific one with a known DNA recognition site long and specific enough ( $9 \mathrm{bp})$ to be discriminating when 


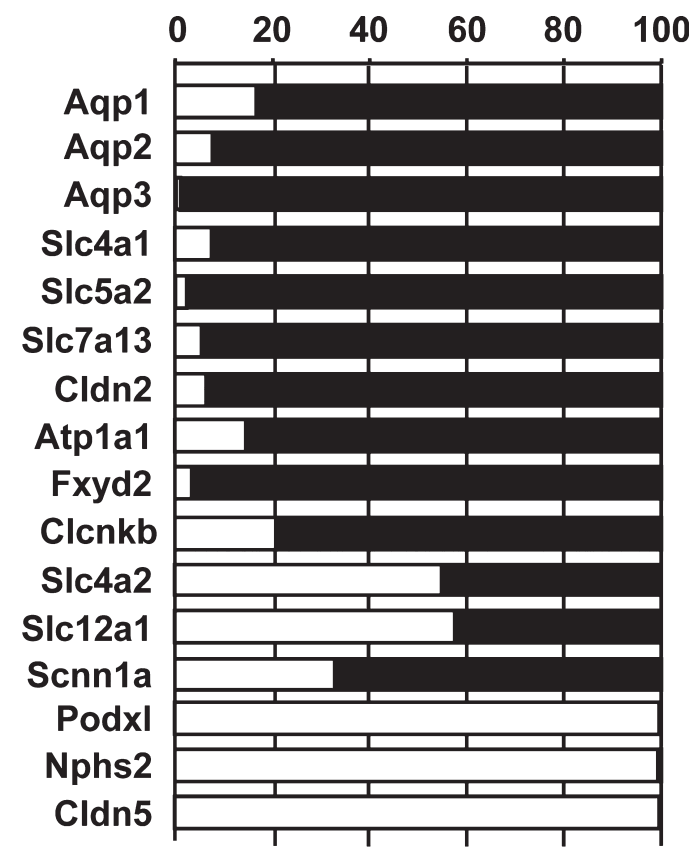

Fig. 5. Localization of gene expression within mouse glomerulus. Expression of claudins, podocyte markers, water channels and ion carriers, channels, and ATPases was determined by RT-PCR on microdissected mouse glomerular tuft (GT) (open columns) and parietal sheet (black columns). Values are mean percent of the sum of mRNA abundance determined in the 2 glomerular substructures in $4-6$ animals.

searching long DNA fragments for a conserved motif. For glomerulus-specific unambiguous tag-derived transcripts, we were able to retrieve a putative promoter region from 78 cognate genes within the Transcriptional Regulatory Element Database freely available from Cold Spring Harbor Laboratory (http://rulai.cshl.edu/cgi-bin/TRED/tred.cgi?process $=$ home). The selected promoter regions span $1 \mathrm{~kb}$ located at positions -700 to +299 relative to the transcription start site. When several promoter regions were available for a same gene, we selected the highest quality rank one (39). We screened the $78-\mathrm{kb}$ of promoter sequences for the 36 putative binding sites derived by a single mismatch from the Wt1 consensus sequence GCGGGGGCG.

This screening identified 69 recognition sites in 36 different promoter sequences out of the 78 (Table 4) suggesting that $46 \%$ of glomerulus-enriched transcripts might be under the direct control of Wt1. To evaluate the statistical relevance of this finding, we searched for the presence of $\mathrm{Wt} 1$ binding sites in the promoters of non relevant genes. For this purpose we analyzed the 73 promoter regions that could be retrieved from the genes encoding the proximal-enriched transcripts and we identified only $10 \mathrm{Wt} 1$ recognition sites. This number of sites is expected from the arbitrary distribution of bases: Since a 9-bp motif is statistically found every 262,144-bp $\left(4^{9}\right)$, which translates to 0.28 hit in 73 $\mathrm{kbp}$, searching for 36 different 9-bp motifs leads to 10.1 hits $(0.28 \times 36)$.

Proliferation of cells from the parietal sheet of Bowman's capsule. Results in Table 3 suggest a relatively high proliferation/differentiation activity in glomeruli compared with PT or whole kidney. As a matter of fact, in adult kidney, tubular epithelial cells are rather quiescent under normal conditions.
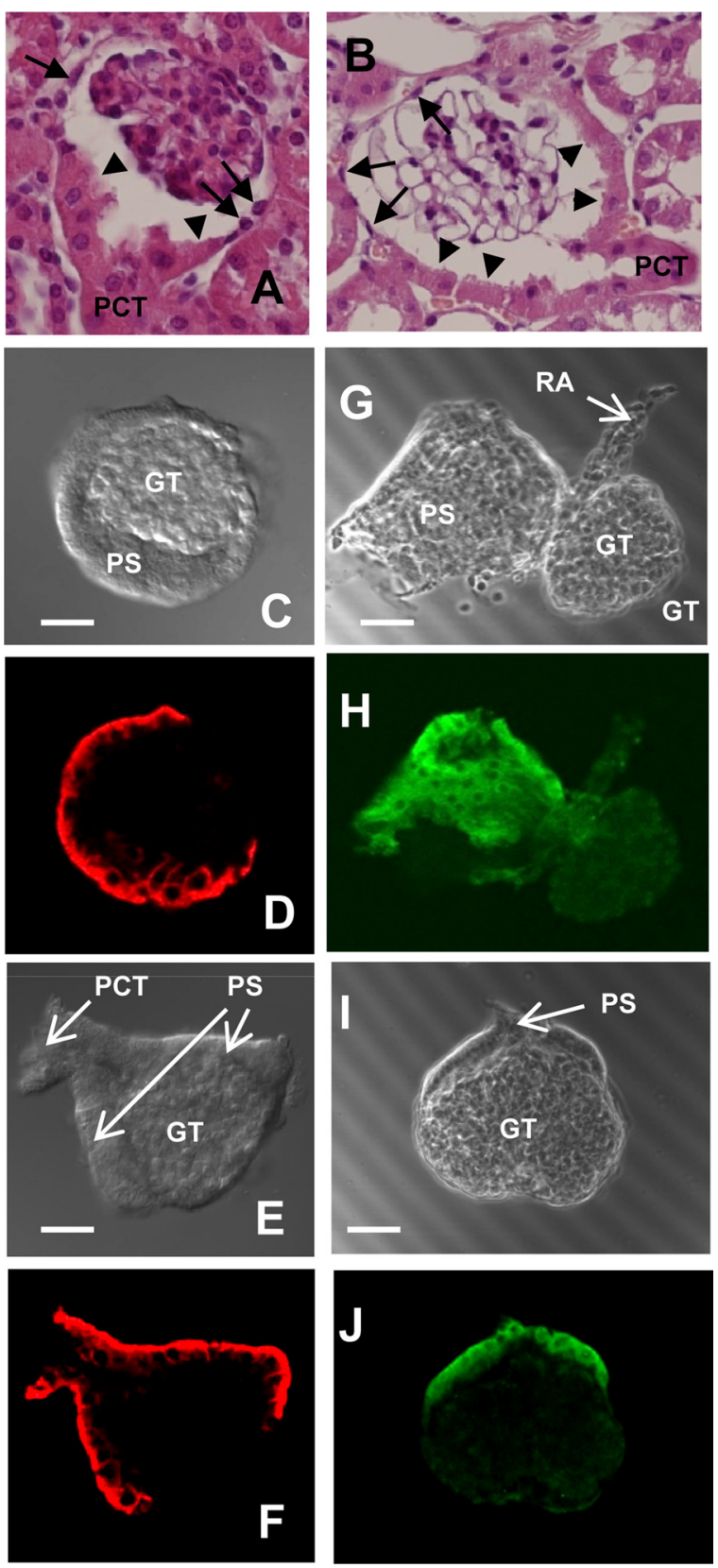

Fig. 6. Structure of mouse glomerular parietal sheet (PS) and expression of Na,K-ATPase $\alpha$-subunit and aquaporin 2 (Aqp2). A, B: hematoxylinstained kidney sections clearly show that the parietal sheet of Bowman's capsule that limits the glomerular urinary space are made of well-differentiated proximal tubule-like cells (PTLCs, arrowheads) that extend from the proximal convoluted tubule (PCT) and flattened parietal epithelial cells (PECs, arrows). $C-J$ : light transmission images $(C, E, G$, and $I)$ and fluorescence images $(D, F, H$, and $J)$ of microdissected mouse glomeruli immunostained with an anti-Na,K-ATPase $\alpha$-subunit antibody $(D$ and $F$, red) or an anti-Aqp2 antibody ( $H$ and $J$, green). On images $E$ and $F$, besides the GT and PS, one can see the initial part of the PCT. On images $G$ and $H$, the GT and the attached glomerular artery (RA) have been partially separated from the PS during microdissection, and one can see the insertion place of the PT on the PS (top of images). Images correspond to median confocal sections of the glomerulus. Within the PS, Na,K-ATPase and Aqp2 staining is restricted to the PTLCs. Size bar: $20 \mu \mathrm{m}$. 
Table 4. Putative targets of Wt1 in glomerulus

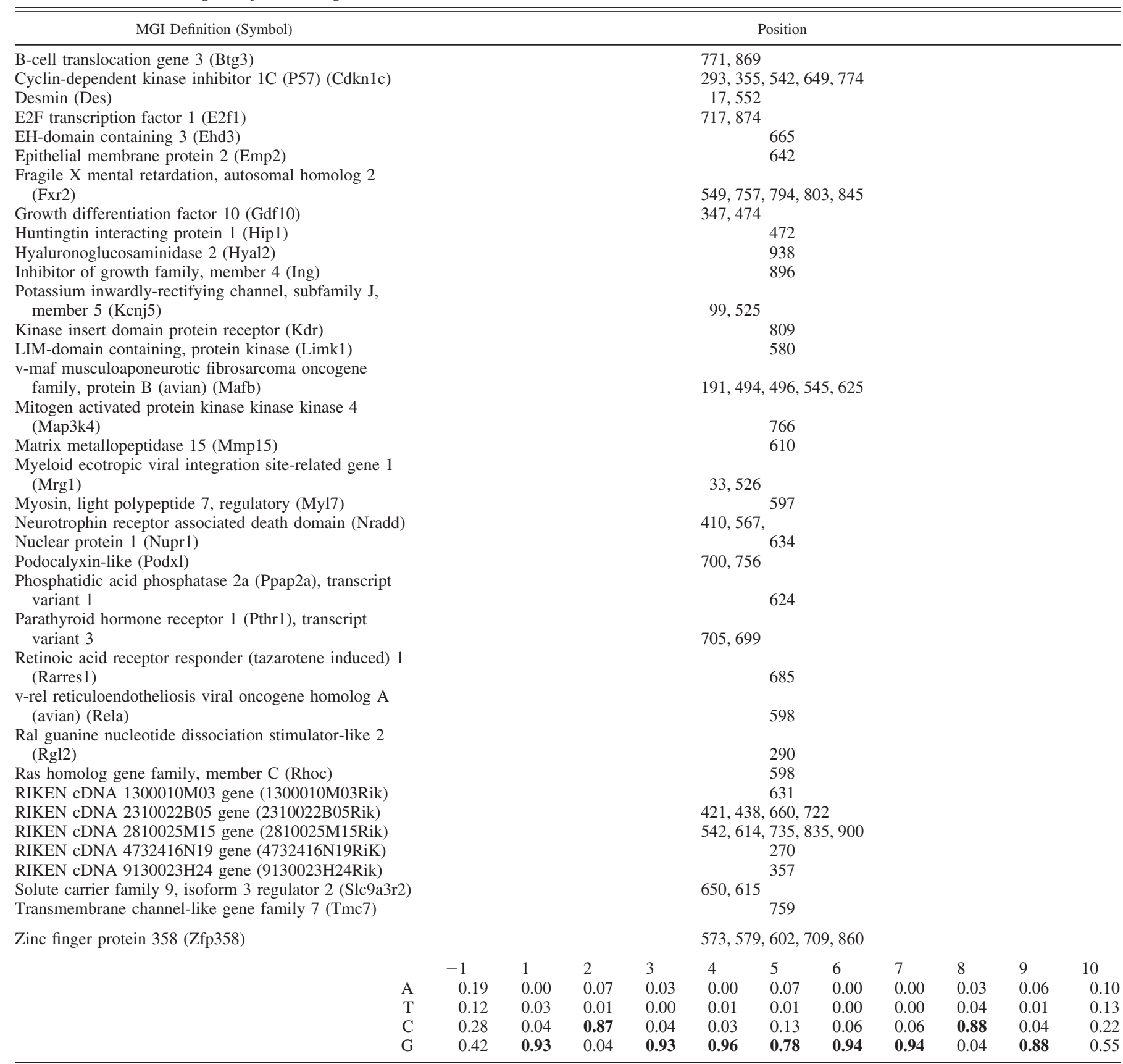

Top: the transcripts containing a Wt1 DNA binding site within their putative promoter region and the position of these sites within the promoter region. Bottom: the matrix consensus binding site defined from these 69 putative sites. Only nucleotides 1-9 were considered for matching with promoter region. Boldface indicates the highest frequences of bases at different positions.

Accordingly, staining of kidney sections for PCNA revealed a much higher density of proliferating cells in the glomerulus than in the remaining part of the kidney parenchyma (Fig. 7A). Within glomeruli, both the glomerular tuft and the parietal sheet contained PCNA-positive cells (Fig. 7, B-E). PCNApositive cells in the parietal sheet were either PECs or PTLCs. Proliferating PTLCs were located almost exclusively at the tip of the proximal tubule-like epithelium, next to PECs (Fig. 7, $B-E$, arrowheads), whereas proliferating PECs were present both close to and far from PTLCs (Fig. 7, $B-E$, asterisks and arrows, respectively).

\section{DISCUSSION}

This study provides a large-scale analysis of gene expression in mouse kidney glomeruli and main tubular structures. SAGE is an essentially quantitative method because tag occurrence quantitatively measures the expression level of cognate transcripts. Thus, it can yield expression profiles of transcripts along the nephron, as shown in Fig. 2 and Tables 1 and 2, but also it allows for a comparison with previously published data in other organs and tissues. SAGE also allows one to compare the expression level of different transcripts in a same structure, 

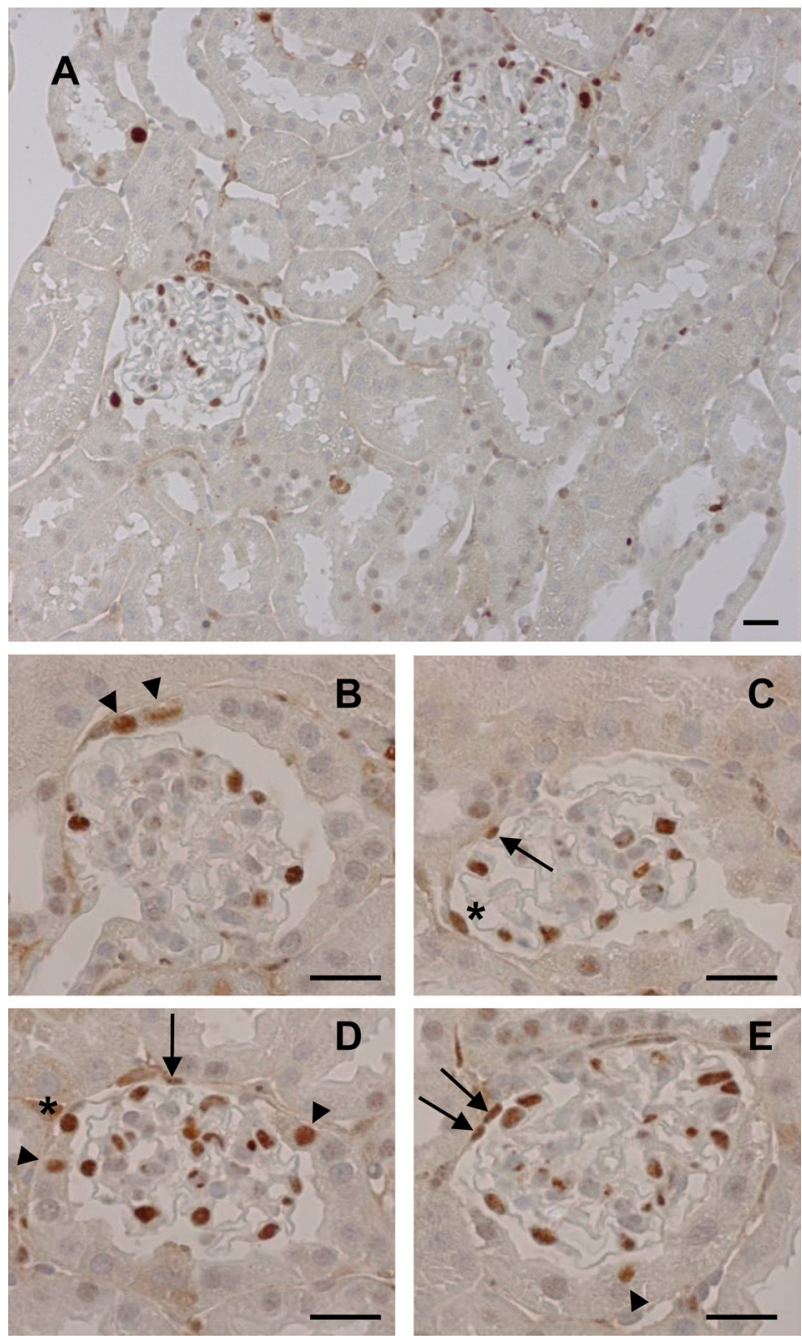

Fig. 7. Localization of PCNA proliferation marker in mouse kidney cortex. $A$ : low-magnification photographs showing that PCNA labeling is mainly, but not exclusively, present in glomeruli. $B-E$ : higher magnification photographs show that both the GT and the PS display PCNA-positive cells. Within the PS, both PECs (arrows and asterisks) and PTLCs (arrowheads) display PCNA labeling. Most proliferating PTLCs were localized at the tip of the proximal tubule-like epithelium, whereas proliferating PECs were present either in the vicinity (*) or far (arrows) from the PTL epithelium. Size bar: $20 \mu \mathrm{m}$.

which remains hardly accurate with other methods such as Q-PCR. This database can also be used for mouse kidney tissue compartmental analysis and all its applications, as recently developed in human kidney (11).

Markers of kidney structures and regions. This SAGE mouse kidney database identifies a large number of tags that are preferentially expressed in single structures or in discrete kidney regions. Their great number in the glomerulus likely reflects the greater cellular heterogeneity of this structure which contains multiple cell types (endothelial and mesangial cells, podocytes, PECs, and PTLCs). As a matter of fact, we found a different gene expression signature between the parietal sheet and the tuft of the glomerulus.

Some of the markers detected in this study are proteins known to be responsible for structure specific functions, such as structural proteins of the glomerulus (e.g., podocin and podocalyxin), ion and water carriers (e.g., aquaporins 1, 2, 3 and $6, \mathrm{NKCC} 2, \mathrm{NCC}$ ), hormone receptors, or signaling kinases (e.g., vasopressin V2 receptor, WNK1). The role of several other markers, including transcripts of unknown function (e.g., RIKEN sequences), in the functional specificity of the different kidney structures remains unknown and should be investigated. For example, despite its very high level of expression in proximal tubules, little is known about Kap function. Early studies reported that Kap interacts with cyclophilin B and protects PT cells from cyclosporine toxicity (6). Despite its basal high expression, the same group unexpectedly reported that transgenesis-induced overexpression of Kap in mouse proximal tubule is associated with hypertension (34).

Role of Wt1 in the glomerulus. The Wt1 gene encodes a transcription factor with four zinc finger motifs. Alternative splicing produces four different isoforms of Wt1. Of the two major isoforms, the - KTS isoform, is involved in cell differentiation and possibly also in proliferation repression, whereas the +KTS isoform, which lacks the DNA-binding domain, is likely involved in mRNA processing.

Wt1 is a tumor suppressor gene, the mutations of which are responsible for Wilms' tumors (15). Wt1 plays a central role in the normal development of kidneys and gonads, and accordingly mutations in the Wt1 gene have been also identified in patients with WAGR syndrome (35), Denys-Drash syndrome (28), Frasier syndrome (3), isolated diffuse mesangial sclerosis (18), and Meacham syndrome (33), all diseases showing defects of glomerular maturation and/or genital abnormalities. Invalidation of the $\mathrm{Wt} 1$ gene in mice confirmed these roles of Wt1 $(10,19,21)$. Recently, the group of Kreidberg (16) has characterized a large number of Wt1 targets during kidney embryogenesis.

Besides its roles during nephrogenesis, Wt1 is expressed in adult podocytes. However, the role of Wt1 in podocyte differentiation and physiology remains mostly unknown in part because most Wt1 targets are not known (24). The finding that functional classification of putative Wt1 target genes revealed a pattern of functions and processes similar to that of glomerulus-enriched genes (data not shown) suggests that Wt1 controls most glomerular-specific functions. Further studies on the putative Wt1 targets identified in this study should help deciphering the roles of Wt1 in the biology of podocytes. It is interesting to note that there is no overlap between Wt1 targets identified in developing kidney (16) and the putative targets here identified in adult podocytes, suggesting clearly distinct roles of Wt1 during embryogenesis and adult physiology. Differences may also be accounted for by methodological reasons. As a matter of fact, podocalyxin, which was identified as a target of Wt1 in embryonic kidney cell precursors (27), was found in our screen but not in that of Kreidberg's group.

Cells of the parietal sheet of Bowman's capsule. Conversely to other species, the mouse glomerular parietal sheet is made of two cell types: classical flattened PECs constitute the vascular pole of the parietal sheet, whereas the urinary pole is made of higher cells with morphological resemblance to cells from the adjacent proximal convoluted tubule, in particular the presence of an apical brush border.

Despite this morphological resemblance, PTLCs differ from PT cells in that they express not only PT markers but also TAL and ASDN ones. It should be stressed, however, that PTLCs do not display the phenotype of fully differentiated multipotent tubule cells. For example, although they express Aqp2, West- 
ern blotting revealed that Aqp2 was not glycosylated (data not shown), whereas only glycosylated Aqp2 is addressed to the apical membrane (17), and these cells do not express the vasopressin receptor (data not shown), which controls membrane expression of Aqp2 in the collecting duct cells. Furthermore, PTLCs display a much higher proliferation rate than tubular cells. Interestingly, proliferating PTLCs were localized at the tip of the PT-like epithelium, next to the PECs. Altogether, these observations suggest that this initial portion of the renal tubule might be a proliferating centre at the origin of progenitors of either proximal or distal tubule cells. The presence of cells with a mixed phenotype of PT and collecting duct is puzzling since, during embryogenesis, the PT and the collecting duct derive from two distinct mesoderm areas, the metanephric mesenchyme and the ureteric bud respectively.

Although PECs share a common origin with podocytes, their differentiation diverges after the S-shaped stage of glomerulogenesis. For example, PECs no longer express Wt1 after this stage of development, whereas podocytes do until adulthood (4). Conversely, mouse PECs express CD10 starting at the capillary loop stage of development, whereas podocytes do not (32). As a result, PECs and podocytes express specific genes in the fully developed kidney (26). Another difference between PECs and podocytes concerns their proliferative capacity. PECs proliferate until the capillary loop stage of development, whereas podocytes do not $(25,32)$. In addition, PECs maintain a proliferation capacity after the end of development as they can enter the cell cycle in response to stimuli during glomerular pathologies, including focal segmental glomerulosclerosis (32). In an elegant study in which they followed PECs lineage, Appel et al. (1) showed that PECs are progenitors of podocytes. Here we showed that mouse PECs display a rather high proliferation rate, even in the absence of glomerular pathology. We also found that some proliferating PECs were located close to PTLCs, suggesting that they might also be progenitors of PTLCs and, consequently, of tubular cells (see above), as proposed in human kidney (31).

We have constructed the first database for quantitative gene expression in the main structures constituting the mouse nephron. Besides being useful for determining the expression pattern of genes of interest, the database may lead to applications related to glomerular biology that open new fields of investigation. Further mining of this freely available database for three types of applications should be fruitful in the near future. Firstly, one should concentrate on the many newly identified structure- and region-enriched transcripts that are not yet functionally characterized. Knowledge accumulated over the past decades has clearly demonstrated the critical role of structure-specific proteins in normal kidney function and in pathological alterations. Thus, this database constitutes a reservoir of potentially important candidates. Secondly, functional classification of structure-specific clusters of transcripts has proven fruitful for discovering an unexpected feature of parietal glomerular cells, i.e., their high proliferation rate. This approach should be extended to other kidney structures or regions. Finally, comparison of human and mouse kidney SAGE libraries should be undertaken to reveal the molecular basis of known differences in renal physiology between these two species, such as the lack of phenotype in mice invalidated for several genes responsible for human kidney diseases.

\section{DISCLOSURES}

No conflicts of interest, financial or otherwise, are declared by the author(s).

\section{REFERENCES}

1. Appel D, Kershaw DB, Smeets B, Yuan G, Fuss A, Frye B, Elger M, Kriz W, Floege J, Moeller MJ. Recruitment of podocytes from glomerular parietal epithelial cells. J Am Soc Nephrol 20: 333-343, 2009.

2. Baginsky S, Hennig L, Zimmermann P, Gruissem W. Gene expression analysis, proteomics, and network discovery. Plant Physiol 152: 402-410, 2010.

3. Barbaux S, Niaudet P, Gubler MC, Grunfeld JP, Jaubert F, Kuttenn F, Fekete CN, Souleyreau-Therville N, Thibaud E, Fellous M, McElreavey K. Donor splice-site mutations in WT1 are responsible for Frasier syndrome. Nat Genet 17: 467-470, 1997.

4. Bariety J, Mandet C, Hill GS, Bruneval P. Parietal podocytes in normal human glomeruli. J Am Soc Nephrol 17: 2770-2780, 2006.

5. Bronson SK, Smithies O. Altering mice by homologous recombination using embryonic stem cells. J Biol Chem 269: 27155-27158, 1994.

6. Cebrian C, Areste C, Nicolas A, Olive P, Carceller A, Piulats J, Meseguer A. Kidney androgen-regulated protein interacts with cyclophilin B and reduces cyclosporine A-mediated toxicity in proximal tubule cells. J Biol Chem 276: 29410-29419, 2001.

7. Chabardes-Garonne D, Mejean A, Aude JC, Cheval L, Di Stefano A, Gaillard MC, Imbert-Teboul M, Wittner M, Balian C, Anthouard V, Robert C, Segurens B, Wincker P, Weissenbach J, Doucet A, Elalouf JM. A panoramic view of gene expression in the human kidney. Proc Natl Acad Sci USA 100: 13710-13715, 2003.

8. Cheval L, Duong Van Huyen JP, Bruneval P, Verbavatz JM, Elalouf JM, Doucet A. Plasticity of mouse renal collecting duct in response to potassium depletion. Physiol Genomics 19: 61-73, 2004.

9. Clarke L, Carbon J. A colony bank containing synthetic Col El hybrid plasmids representative of the entire E. coli genome. Cell 9: 91-99, 1976.

10. Davies JA, Ladomery M, Hohenstein P, Michael L, Shafe A, Spraggon L, Hastie N. Development of an siRNA-based method for repressing specific genes in renal organ culture and its use to show that the Wt1 tumour suppressor is required for nephron differentiation. Hum Mol Genet 13: 235-246, 2004.

11. Disset A, Cheval L, Soutourina O, Duong Van Huyen JP, Li G, Genin C, Tostain J, Loupy A, Doucet A, Rajerison R. Tissue compartment analysis for biomarker discovery by gene expression profiling. PLoS One 4: e7779, 2009.

12. Eisen MB, Spellman PT, Brown PO, Botstein D. Cluster analysis and display of genome-wide expression patterns. Proc Natl Acad Sci USA 95: 14863-14868, 1998.

13. Emmersen J, Heidenblut AM, Hogh AL, Hahn SA, Welinder KG, Nielsen KL. Discarding duplicate ditags in LongSAGE analysis may introduce significant error. BMC Bioinformatics 8: 92, 2007.

14. Gibbs RA, Weinstock GM, Metzker ML, Muzny DM, Sodergren EJ, Scherer S, Scott G, Steffen D, Worley KC, Burch PE, Okwuonu G, Hines S, Lewis L, DeRamo C, Delgado O, Dugan-Rocha S, Miner G, Morgan M, Hawes A, Gill R, Celera Holt RA, Adams MD, Amanatides PG, Baden-Tillson H, Barnstead M, Chin S, Evans CA, Ferriera S, Fosler C, Glodek A, Gu Z, Jennings D, Kraft CL, Nguyen T, Pfannkoch CM, Sitter C, Sutton GG, Venter JC, Woodage T, Smith D, Lee HM, Gustafson E, Cahill P, Kana A, Doucette-Stamm L, Weinstock K, Fechtel K, Weiss RB, Dunn DM, Green ED, Blakesley RW, Bouffard GG, De Jong PJ, Osoegawa K, Zhu B, Marra M, Schein J, Bosdet I, Fjell C, Jones S, Krzywinski M, Mathewson C, Siddiqui A, Wye N, McPherson J, Zhao S, Fraser CM, Shetty J, Shatsman S, Geer K, Chen Y, Abramzon S, Nierman WC, Havlak PH, Chen R, Durbin KJ, Egan A, Ren Y, Song XZ, Li B, Liu Y, Qin X, Cawley S, Worley KC, Cooney AJ, D'Souza LM, Martin K, Wu JQ, Gonzalez-Garay ML, Jackson AR, Kalafus KJ, McLeod MP, Milosavljevic A, Virk D, Volkov A, Wheeler DA, Zhang Z, Bailey JA, Eichler EE, Tuzun E, Birney E, Mongin E, Ureta-Vidal A, Woodwark C, Zdobnov E, Bork P, Suyama M, Torrents D, Alexandersson M, Trask BJ, Young JM, Huang H, Wang H, Xing H, Daniels S, Gietzen D, Schmidt J, Stevens K, Vitt U, Wingrove J, Camara F, Mar Alba M, Abril JF, Guigo R, Smit A, Dubchak I, Rubin EM, Couronne O, Poliakov A, Hubner N, Ganten D, Goesele C, Hummel O, Kreitler T, Lee YA, Monti J, Schulz H, Zimdahl H, Himmelbauer H, Lehrach H, Jacob HJ, Bromberg S, Gullings-Handley J, Jensen-Seaman MI, Kwitek AE, Lazar J, Pasko D, Tonellato PJ, Twigger S, Ponting 
CP, Duarte JM, Rice S, Goodstadt L, Beatson SA, Emes RD, Winter EE, Webber C, Brandt P, Nyakatura G, Adetobi M, Chiaromonte F, Elnitski L, Eswara P, Hardison RC, Hou M, Kolbe D, Makova K, Miller W, Nekrutenko A, Riemer C, Schwartz S, Taylor J, Yang S, Zhang Y, Lindpaintner K, Andrews TD, Caccamo M, Clamp M, Clarke L, Curwen V, Durbin R, Eyras E, Searle SM, Cooper GM, Batzoglou S, Brudno M, Sidow A, Stone EA, Venter JC, Payseur BA, Bourque G, Lopez-Otin C, Puente XS, Chakrabarti K, Chatterji S, Dewey C, Pachter L, Bray N, Yap VB, Caspi A, Tesler G, Pevzner PA, Haussler D, Roskin KM, Baertsch R, Clawson H, Furey TS, Hinrichs AS, Karolchik D, Kent WJ, Rosenbloom KR, Trumbower H, Weirauch M, Cooper DN, Stenson PD, Ma B, Brent M, Arumugam M, Shteynberg D, Copley RR, Taylor MS, Riethman H, Mudunuri U, Peterson J, Guyer M, Felsenfeld A, Old S, Mockrin S, Collins F. Genome sequence of the Brown Norway rat yields insights into mammalian evolution. Nature 428: 493-521, 2004

15. Haber DA, Buckler AJ, Glaser T, Call KM, Pelletier J, Sohn RL, Douglass EC, Housman DE. An internal deletion within an $11 \mathrm{p} 13$ zinc finger gene contributes to the development of Wilms' tumor. Cell 61: 1257-1269, 1990.

16. Hartwig S, Ho J, Pandey P, Macisaac K, Taglienti M, Xiang M, Alterovitz G, Ramoni M, Fraenkel E, Kreidberg JA. Genomic characterization of Wilms' tumor suppressor 1 targets in nephron progenitor cells during kidney development. Development 137: 1189-1203, 2010

17. Hendriks G, Koudijs M, van Balkom BW, Oorschot V, Klumperman J, Deen PM, van der Sluijs P. Glycosylation is important for cell surface expression of the water channel aquaporin-2 but is not essential for tetramerization in the endoplasmic reticulum. J Biol Chem 279: 29752983, 2004.

18. Jeanpierre C, Denamur E, Henry I, Cabanis MO, Luce S, Cecille A, Elion J, Peuchmaur M, Loirat C, Niaudet P, Gubler MC, Junien C. Identification of constitutional WT1 mutations, in patients with isolated diffuse mesangial sclerosis, and analysis of genotype/phenotype correlations by use of a computerized mutation database. Am J Hum Genet 62: 824-833, 1998.

19. Kreidberg JA, Sariola H, Loring JM, Maeda M, Pelletier J, Housman D, Jaenisch R. WT-1 is required for early kidney development. Cell 74: 679-691, 1993.

20. Lander ES, Linton LM, Birren B, Nusbaum C, Zody MC, Baldwin J, Devon K, Dewar K, Doyle M, FitzHugh W, Funke R, Gage D, Harris K, Heaford A, Howland J, Kann L, Lehoczky J, LeVine R, McEwan P, McKernan K, Meldrim J, Mesirov JP, Miranda C, Morris W, Naylor J, Raymond C, Rosetti M, Santos R, Sheridan A, Sougnez C, Stange-Thomann N, Stojanovic N, Subramanian A, Wyman D, Rogers J, Sulston J, Ainscough R, Beck S, Bentley D, Burton J, Clee C, Carter $\mathbf{N}$, Coulson A, Deadman R, Deloukas P, Dunham A, Dunham I, Durbin R, French L, Grafham D, Gregory S, Hubbard T, Humphray S, Hunt A, Jones M, Lloyd C, McMurray A, Matthews L, Mercer S, Milne S, Mullikin JC, Mungall A, Plumb R, Ross M, Shownkeen R, Sims S, Waterston RH, Wilson RK, Hillier LW, McPherson JD, Marra MA, Mardis ER, Fulton LA, Chinwalla AT, Pepin KH, Gish WR, Chissoe SL, Wendl MC, Delehaunty KD, Miner TL, Delehaunty A, Kramer JB, Cook LL, Fulton RS, Johnson DL, Minx PJ, Clifton SW, Hawkins T, Branscomb E, Predki P, Richardson P, Wenning S, Slezak T, Doggett N, Cheng JF, Olsen A, Lucas S, Elkin C, Uberbacher E, Frazier M, Gibbs RA, Muzny DM, Scherer SE, Bouck JBSodergren EJ, Worley KC, Rives CM, Gorrell JH, Metzker ML, Naylor SL, Kucherlapati RS, Nelson DL, Weinstock GM, Sakaki Y, Fujiyama A, Hattori M, Yada T, Toyoda A, Itoh T, Kawagoe C, Watanabe H, Totoki Y, Taylor T, Weissenbach J, Heilig R, Saurin W, Artiguenave F, Brottier P, Bruls T, Pelletier E, Robert C, Wincker P, Smith DR, Doucette-Stamm L, Rubenfield M, Weinstock K, Lee HM, Dubois J, Rosenthal A, Platzer M, Nyakatura G, Taudien S, Rump A, Yang H, Yu J, Wang J, Huang G, Gu J, Hood L, Rowen L, Madan A, Qin S, Davis RW, Federspiel NA, Abola AP, Proctor MJ, Myers RM, Schmutz J, Dickson M, Grimwood J, Cox DR, Olson MV, Kaul R, Raymond C, Shimizu N, Kawasaki K, Minoshima S, Evans GA, Athanasiou M, Schultz R, Roe BA, Chen F, Pan H, Ramser J, Lehrach H, Reinhardt R, McCombie WR, de la Bastide M, Dedhia N, Blocker H, Hornischer K, Nordsiek G, Agarwala R, Aravind L, Bailey JA, Bateman A, Batzoglou S, Birney E, Bork P, Brown DG, Burge CB, Cerutti L, Chen HC, Church D, Clamp M, Copley RR, Doerks T, Eddy SR, Eichler EE, Furey TS, Galagan J, Gilbert JG, Harmon C, Hayashizaki Y, Haussler D, Hermjakob H, Hokamp K, Jang
W, Johnson LS, Jones TA, Kasif S, Kaspryzk A, Kennedy S, Kent WJ, Kitts P, Koonin EV, Korf I, Kulp D, Lancet D, Lowe TM, McLysaght A, Mikkelsen T, Moran JV, Mulder N, Pollara VJ, Ponting CP, Schuler G, Schultz J, Slater G, Smit AF, Stupka E, Szustakowski J, Thierry-Mieg D, Thierry-Mieg J, Wagner L, Wallis J, Wheeler R, Williams A, Wolf YI, Wolfe KH, Yang SP, Yeh RF, Collins F, Guyer MS, Peterson J, Felsenfeld A, Wetterstrand KA, Patrinos A, Morgan MJ, de Jong P, Catanese JJ, Osoegawa K, Shizuya H, Choi S, Chen YJ. Initial sequencing and analysis of the human genome. Nature 409: 860-921, 2001.

21. Moore AW, McInnes L, Kreidberg J, Hastie ND, Schedl A. YAC complementation shows a requirement for $\mathrm{Wt} 1$ in the development of epicardium, adrenal gland and throughout nephrogenesis. Development 126: 1845-1857, 1999.

22. Morla L, Crambert G, Mordasini D, Favre G, Doucet A, ImbertTeboul M. Proteinase-activated receptor 2 stimulates Na,K-ATPase and sodium reabsorption in native kidney epithelium. J Biol Chem 283: 28020-28028, 2008

23. Morozova O, Hirst M, Marra MA. Applications of new sequencing technologies for transcriptome analysis. Annu Rev Genomics Hum Genet 10: $135-151,2009$.

24. Morrison AA, Viney RL, Saleem MA, Ladomery MR. New insights into the function of the Wilms tumor suppressor gene WT1 in podocytes. Am J Physiol Renal Physiol 295: F12-F17, 2008.

25. Nagata M, Yamaguchi Y, Ito K. Loss of mitotic activity and the expression of vimentin in glomerular epithelial cells of developing human kidneys. Anat Embryol (Berl) 187: 275-279, 1993.

26. Ohse T, Pippin JW, Chang AM, Krofft RD, Miner JH, Vaughan MR, Shankland SJ. The enigmatic parietal epithelial cell is finally getting noticed: a review. Kidney Int 76: 1225-1238, 2009.

27. Palmer RE, Kotsianti A, Cadman B, Boyd T, Gerald W, Haber DA. WT1 regulates the expression of the major glomerular podocyte membrane protein Podocalyxin. Curr Biol 11: 1805-1809, 2001.

28. Pelletier J, Bruening W, Kashtan CE, Mauer SM, Manivel JC, Striegel JE, Houghton DC, Junien C, Habib R, Fouser L, Fine RN, Silverman BL, Haber DA, Housman D. Germline mutations in the Wilms' tumor suppressor gene are associated with abnormal urogenital development in Denys-Drash syndrome. Cell 67: 437-447, 1991.

29. Piquemal D, Commes T, Manchon L, Lejeune M, Ferraz C, Pugnere D, Demaille J, Elalouf JM, Marti J. Transcriptome analysis of monocytic leukemia cell differentiation. Genomics 80: 361-371, 2002.

30. Quere R, Manchon L, Lejeune M, Clement O, Pierrat F, Bonafoux B, Commes T, Piquemal D, Marti J. Mining SAGE data allows large-scale, sensitive screening of antisense transcript expression. Nucleic Acids Res 32: e163, 2004.

31. Ronconi E, Sagrinati C, Angelotti ML, Lazzeri E, Mazzinghi B, Ballerini L, Parente E, Becherucci F, Gacci M, Carini M, Maggi E, Serio M, Vannelli GB, Lasagni L, Romagnani S, Romagnani P. Regeneration of glomerular podocytes by human renal progenitors. $J$ Am Soc Nephrol 20: 322-332, 2009.

32. Smeets B, Dijkman HB, Wetzels JF, Steenbergen EJ. Lessons from studies on focal segmental glomerulosclerosis: an important role for parietal epithelial cells? J Pathol 210: 263-272, 2006.

33. Suri M, Kelehan P, O’Neill D, Vadeyar S, Grant J, Ahmed SF, Tolmie J, McCann E, Lam W, Smith S, Fitzpatrick D, Hastie ND, Reardon W. WT1 mutations in Meacham syndrome suggest a coelomic mesothelial origin of the cardiac and diaphragmatic malformations. Am J Med Genet A 143A: 2312-2320, 2007.

34. Tornavaca O, Pascual G, Barreiro ML, Grande MT, Carretero A, Riera M, Garcia-Arumi E, Bardaji B, Gonzalez-Nunez M, Montero MA, Lopez-Novoa JM, Meseguer A. Kidney androgen-regulated protein transgenic mice show hypertension and renal alterations mediated by oxidative stress. Circulation 119: 1908-1917, 2009.

35. Van Heyningen V, Bickmore WA, Seawright A, Fletcher JM, Maule J, Fekete G, Gessler M, Bruns GA, Huerre-Jeanpierre C, Junien C, Williams BRG, Hastie ND. Role for the Wilms tumor gene in genital development? Proc Natl Acad Sci USA 87: 5383-5386, 1990.

36. Venter JC, Adams MD, Myers EW, Li PW, Mural RJ, Sutton GG, Smith HO, Yandell M, Evans CA, Holt RA, Gocayne JD, Amanatides P, Ballew RM, Huson DH, Wortman JR, Zhang Q, Kodira CD, Zheng XH, Chen L, Skupski M, Subramanian G, Thomas PD, Zhang J, Gabor Miklos GL, Nelson C, Broder S, Clark AG, Nadeau J, McKusick VA, Zinder N, Levine AJ, Roberts RJ, Simon M, Slayman C, Hunkapiller M, Bolanos R, Delcher A, Dew I, Fasulo D, Flanigan M, 
Florea L, Halpern A, Hannenhalli S, Kravitz S, Levy S, Mobarry C, Reinert K, Remington K, Abu-Threideh J, Beasley E, Biddick K, Bonazzi V, Brandon R, Cargill M, Chandramouliswaran I, Charlab R, Chaturvedi K, Deng Z, Di Francesco V, Dunn P, Eilbeck K, Evangelista C, Gabrielian AE, Gan W, Ge W, Gong F, Gu Z, Guan P, Heiman TJ, Higgins ME, Ji RR, Ke Z, Ketchum KA, Lai Z, Lei Y, Li Z, Li J, Liang Y, Lin X, Lu F, Merkulov GV, Milshina N, Moore HM, Naik AK, Narayan VA, Neelam B, Nusskern D, Rusch DB, Salzberg S, Shao W, Shue B, Sun J, Wang Z, Wang A, Wang X, Wang J, Wei M, Wides R, Xiao C, Yan C, Yao A, Ye J, Zhan M, Zhang W, Zhang H, Zhao Q, Zheng L, Zhong F, Zhong W, Zhu S, Zhao S, Gilbert D, Baumhueter S, Spier G, Carter C, Cravchik A, Woodage T, Ali F, An H, Awe A, Baldwin D, Baden H, Barnstead M, Barrow I, Beeson K, Busam D, Carver A, Center A, Cheng ML, Curry L, Danaher S, Davenport L, Desilets R, Dietz S, Dodson K, Doup L, Ferriera S, Garg N, Gluecksmann A, Hart B, Haynes J, Haynes C, Heiner C, Hladun S, Hostin D, Houck J, Howland T, Ibegwam C, Johnson J, Kalush F, Kline L, Koduru S, Love A, Mann F, May D, McCawley S, McIntosh T, McMullen I, Moy M, Moy L, Murphy B, Nelson K, Pfannkoch C, Pratts E, Puri V, Qureshi H, Reardon M, Rodriguez R, Rogers YH, Romblad D, Ruhfel B, Scott R, Sitter C, Smallwood M, Stewart E, Strong R, Suh E, Thomas R, Tint NN, Tse S, Vech C, Wang G, Wetter J, Williams S, Williams M, Windsor S, Winn-Deen E, Wolfe K, Zaveri J, Zaveri K, Abril JF, Guigo R, Campbell MJ, Sjolander KV, Karlak B, Kejariwal A, Mi H, Lazareva B, Hatton T, Narechania A, Diemer K, Muruganujan A, Guo N, Sato S, Bafna V, Istrail S, Lippert R, Schwartz R, Walenz B, Yooseph S, Allen D, Basu A, Baxendale J, Blick L, Caminha M, Carnes-Stine J, Caulk P, Chiang YH, Coyne M, Dahlke C, Mays A, Dombroski M, Donnelly M, Ely D, Esparham S, Fosler C, Gire H, Glanowski S, Glasser K, Glodek A, Gorokhov M, Graham K, Gropman B, Harris M, Heil J, Henderson S, Hoover J, Jennings D, Jordan C, Jordan J, Kasha J, Kagan L, Kraft C, Levitsky A, Lewis M, Liu X, Lopez J, Ma D, Majoros W, McDaniel J, Murphy S, Newman M, Nguyen T, Nguyen N, Nodell M, Pan S, Peck J, Peterson M, Rowe W, Sanders R, Scott J, Simpson M, Smith T, Sprague A, Stockwell T, Turner R, Venter E, Wang M, Wen M, Wu D, Wu M, Xia A, Zandieh A, Zhu X. The sequence of the human genome. Science 291: 1304-1351, 2001.

37. Virlon B, Cheval L, Buhler JM, Billon E, Doucet A, Elalouf JM. Serial microanalysis of renal transcriptomes. Proc Natl Acad Sci USA 96: 15286-15291, 1999.

38. Waterston RH, Lindblad-Toh K, Birney E, Rogers J, Abril JF, Agarwal P, Agarwala R, Ainscough R, Alexandersson M, An P, Antonarakis SE, Attwood J, Baertsch R, Bailey J, Barlow K, Beck S,
Berry E, Birren B, Bloom T, Bork P, Botcherby M, Bray N, Brent MR, Brown DG, Brown SD, Bult C, Burton J, Butler J, Campbell RD, Carninci P, Cawley S, Chiaromonte F, Chinwalla AT, Church DM, Clamp M, Clee C, Collins FS, Cook LL, Copley RR, Coulson A, Couronne O, Cuff J, Curwen V, Cutts T, Daly M, David R, Davies J, Delehaunty KD, Deri J, Dermitzakis ET, Dewey C, Dickens NJ, Diekhans M, Dodge S, Dubchak I, Dunn DM, Eddy SR, Elnitski L, Emes RD, Eswara P, Eyras E, Felsenfeld A, Fewell GA, Flicek P, Foley K, Frankel WN, Fulton LA, Fulton RS, Furey TS, Gage D, Gibbs RA, Glusman G, Gnerre S, Goldman N, Goodstadt L, Grafham D, Graves TA, Green ED, Gregory S, Guigo R, Guyer M, Hardison RC, Haussler D, Hayashizaki Y, Hillier LW, Hinrichs A, Hlavina W, Holzer T, Hsu F, Hua A, Hubbard T, Hunt A, Jackson I, Jaffe DB, Johnson LS, Jones M, Jones TA, Joy A, Kamal M, Karlsson EK, Karolchik D, Kasprzyk A, Kawai J, Keibler E, Kells C, Kent WJ, Kirby A, Kolbe DL, Korf I, Kucherlapati RS, Kulbokas EJ, Kulp D, Landers T, Leger JP, Leonard S, Letunic I, Levine R, Li J, Li M, Lloyd C, Lucas S, Ma B, Maglott DR, Mardis ER, Matthews L, Mauceli E, Mayer JH, McCarthy M, McCombie WR, McLaren S, McLay K, McPherson JD, Meldrim J, Meredith B, Mesirov JP, Miller W, Miner TL, Mongin E, Montgomery KT, Morgan M, Mott R, Mullikin JC, Muzny DM, Nash WE, Nelson JO, Nhan MN, Nicol R, Ning Z, Nusbaum C, O'Connor MJ, Okazaki Y, Oliver K, OvertonLarty E, Pachter L, Parra G, Pepin KH, Peterson J, Pevzner P, Plumb R, Pohl CS, Poliakov A, Ponce TC, Ponting CP, Potter S, Quail M, Reymond A, Roe BA, Roskin KM, Rubin EM, Rust AG, Santos R, Sapojnikov V, Schultz B, Schultz J, Schwartz MS, Schwartz S, Scott C, Seaman S, Searle S, Sharpe T, Sheridan A, Shownkeen R, Sims S, Singer JB, Slater G, Smit A, Smith DR, Spencer B, Stabenau A, Stange-Thomann N, Sugnet C, Suyama M, Tesler G, Thompson J, Torrents D, Trevaskis E, Tromp J, Ucla C, Ureta-Vidal A, Vinson JP, Von Niederhausern AC, Wade CM, Wall M, Weber RJ, Weiss RB, Wendl MC, West AP, Wetterstrand K, Wheeler R, Whelan S, Wierzbowski J, Willey D, Williams S, Wilson RK, Winter E, Worley KC, Wyman D, Yang S, Yang SP, Zdobnov EM, Zody MC, Lander ES. Initial sequencing and comparative analysis of the mouse genome. Nature 420: 520-562, 2002.

39. Xuan Z, Zhao F, Wang J, Chen G, Zhang MQ. Genome-wide promoter extraction and analysis in human, mouse, and rat. Genome Biol 6: R72, 2005.

40. Zuber AM, Centeno G, Pradervand S, Nikolaeva S, Maquelin L, Cardinaux L, Bonny O, Firsov D. Molecular clock is involved in predictive circadian adjustment of renal function. Proc Natl Acad Sci USA 106: 16523-16528, 2009. 